\title{
Late Neolithic Mondsee Culture in Austria: living on lakes and living with flood risk?
}

\author{
T. Swierczynski, S. Lauterbach, P. Dulski, and A. Brauer \\ GFZ German Research Centre for Geosciences, Section 5.2 - Climate Dynamics and Landscape Evolution, \\ Telegrafenberg, 14473 Potsdam, Germany \\ Correspondence to: T. Swierczynski (swier@gfz-potsdam.de)
}

Received: 14 November 2012 - Published in Clim. Past Discuss.: 29 November 2012

Revised: 24 May 2013 - Accepted: 15 June 2013 - Published: 23 July 2013

\begin{abstract}
Neolithic and Bronze Age lake dwellings in the European Alps became recently protected under the UNESCO World Heritage. However, only little is known about the cultural history of the related pre-historic communities, their adaptation strategies to environmental changes and particularly about the almost synchronous decline of many of these settlements around the transition from the Late Neolithic to the Early Bronze Age. For example, there is an ongoing debate whether the abandonment of Late Neolithic lake dwellings at Lake Mondsee (Upper Austria) was caused by unfavourable climate conditions or a single catastrophic event. Within the varved sediments of Lake Mondsee, we investigated the occurrence of intercalated detrital layers from major floods and debris flows to unravel extreme surface runoff recurrence during the Neolithic settlement period. A combination of detailed sediment microfacies analysis and $\mu \mathrm{XRF}$ element scanning allows distinguishing debris flow and flood deposits. A total of 60 flood and 12 debris flow event layers was detected between 7000 and 4000 varve years (vyr) BP. Compared to the centennial- to millennialscale average, a period of increased runoff event frequency can be identified between 5900 and 4450 vyr BP. Enhanced flood frequency is accompanied by predominantly siliciclastic sediment supply between ca. 5500 and 5000 vyr BP and enhanced dolomitic sediment supply between 4900 and $4500 \mathrm{vyr}$ BP. A change in the location and the construction technique of the Neolithic lake dwellings at Lake Mondsee can be observed during the period of higher flood frequency. While lake dwellings of the first settlement period (ca. 58005250 cal. yr BP) were constructed directly on the wetlands, later constructions (ca. 5400-4700 cal. yr BP) were built on piles upon the water, possibly indicating an adaptation to ei-
\end{abstract}

ther increased flood risk or a general increase of the lake level. However, our results also indicate that other than climatic factors (e.g. socio-economic changes) must have influenced the decline of the Mondsee Culture because flood activity generally decreased since 4450 vyr BP, but no new lake dwellings have been established thereafter.

\section{Introduction}

Catastrophic impacts of past climatic changes on pre-historic societies have been the topic of several studies during the last decade (e.g. deMenocal, 2001; Haug et al., 2003; Staubwasser et al., 2003; Webster et al., 2007; Yancheva et al., 2007). However, the demise of ancient civilisations might be more likely driven by a complex interplay of changing environmental conditions and other factors such as socioeconomic changes or natural disasters (e.g. Magny, 2004; Fedele et al., 2008), but distinguishing between these remains difficult. Unfavourable climate conditions have for example been proposed to be a major cause of the large-scale and broadly synchronous abandonment of lake dwellings in the Alpine region at the transition between the Neolithic and the Bronze Age (Magny, 1993, 2004). In particular, a cold reversal, reflected by rising lake levels (Magny, 2004; Magny and Haas, 2004) and glacier advances (Ivy-Ochs et al., 2009), between 5600 and $5300 \mathrm{cal}$. yr BP has been identified, which probably affected Neolithic cultures in the circum-Alpine region. In this context, there is indication that climatic changes might have also been responsible for the decline of the Late Neolithic Mondsee Culture of Upper Austria (Offenberger, 1986; Schmidt, 1986), which existed between ca. 5650 and 
5050 cal. yr BP (Ruttkay et al., 2004). Although this apparently supports the proposed significant influence of climate change on pre-historic settlements in the Alps, a catastrophic landslide has also been assumed to have caused the disappearance of lake dwellings at this site (Janik, 1969; Schulz, 2008). Hence, further studies are necessary to unravel the local factors leading to the abandonment of Neolithic settlements at Lake Mondsee. This might also provide valuable information about the impact of climate variability on $\mathrm{Ne}$ olithic lake-shore settlements on a larger spatial scale. However, the limited temporal resolution and chronological precision of different geoarchives still represents a major obstacle in investigating the influence of climate change and shortterm hydro-meteorological events on early human societies and their settlements and further studies are needed to sufficiently address this issue. Within this context, annually laminated lake sediments, which are characterised by a robust age control and record climatic changes directly in the habitat of the pre-historic lake dwellers, can provide valuable information about past environmental conditions (e.g. hydrological changes) and their influence on the settlements.

The varved sediments of Lake Mondsee (Upper Austria) represent an ideal archive of past climate history and changing environmental conditions (e.g. Klee and Schmidt, 1987; Schultze and Niederreiter, 1990; Schmidt, 1991; Lauterbach et al., 2011) and more specifically of past changes in flood frequencies (Swierczynski et al., 2012). The present study of Lake Mondsee sediments focuses on flood and debris flow event layer deposition between 7000 and 4000 varve years (vyr) BP, providing information about hydrological changes within this interval at high temporal resolution. The established unique event chronology enables, in comparison to radiocarbon dates from three Neolithic lake-dwelling sites around the lake (Felber and Pak, 1973; Felber, 1970, 1974, 1975, 1985; Schmidt, 1986, Dworsky and Reitmaier, 2004), the evaluation of possible impacts of changes in runoff activity on the decline of Neolithic lake dwellings at Lake Mondsee. Furthermore, the hypothesis of a single catastrophic event as the cause for the abandonment of the Neolithic settlements is discussed.

\section{Study area}

Lake Mondsee is located at the northeastern fringe of the European Alps (Upper Austria, 47 $49^{\prime} \mathrm{N}, 13^{\circ} 24^{\prime} \mathrm{E}, 481 \mathrm{~m}$ above sea level), about $40 \mathrm{~km}$ east of Salzburg (Fig. 1). The lake has a surface area of about $14 \mathrm{~km}^{2}$ and a maximum depth of $68 \mathrm{~m}$. The lake basin can be divided into a shallower northern and a deeper southern part, which are separated by a small sill and characterised by different limnophysical conditions (Jagsch and Megay, 1982). Three main rivers (Griesler Ache/Fuschler Ache, Zeller Ache and Wangauer Ache) feed the northern part of the lake basin, whereas only several smaller streams discharge into the southern part.
The only outlet (Seeache) is located at the southern end of Lake Mondsee and drains into Lake Attersee. A Tertiary thrust fault, tracking along the southern lake shoreline, divides the catchment $\left(\sim 247 \mathrm{~km}^{2}\right)$ into a southern and a northern part with two different, clearly distinguishable geological units (Fig. 1). Rhenodanubic Flysch sediments and Last Glacial moraines characterise the gentle hills around the northern part of the lake basin, whereas the southern shoreline of the lake is defined by the steep-sloping mountains of the Northern Calcareous Alps, composed of Triassic Main Dolomite and Mesozoic limestones.

The climate of the Lake Mondsee region is influenced by Atlantic and Mediterranean air masses (Sodemann and Zubler, 2010) and characterised by warm summers and frequent precipitation (annual average $\sim 1550 \mathrm{~mm}$ for the period 1971-2000, Central Institute for Meteorology and Geodynamics (ZAMG), Vienna, Austria). As typical for the NE Alps, the precipitation maximum and in consequence extreme floods occur in July and August (Parajka et al., 2010). As indicated by historical records of daily lake water level for the last $100 \mathrm{yr}$, only very few flood events occur in winter (e.g. 1974) and autumn (e.g. 1899, 1920) (Swierczynski et al., 2009).

\section{Neolithic lake dwellings at Lake Mondsee}

First research on pre-historic lake dwellings in the European Alps, since 2011 protected under the UNESCO World Heritage, was already published in the mid-19th century (Keller, 1854), reporting the finding of a submerged Bronze Age settlement in Lake Zurich. Within the following decades, several other Neolithic and Bronze Age settlements along pre-Alpine and Alpine lakes were discovered, accompanied by a lively debate about construction techniques and the socio-cultural and environmental conditions during the time interval of settlement (see Menotti, 2001, 2004, 2009, for a review).

So far, three lake-dwelling sites have been discovered along the shorelines of the southern basin of Lake Mondsee in the Salzkammergut Lake District (Fig. 1). Radiocarbon dates obtained from several wooden artefacts from these lake dwellings clearly indicate a Young to Final Neolithic age, dating between ca. 5900 and 4500 cal. yr BP (Felber and Pak, 1973; Felber, 1970, 1974, 1975, 1985; Dworsky and Reitmaier, 2004; Ruttkay et al., 2004). The site "See", which has already been described in the second half of the 19th century (Much, 1872, 1874, 1876) and after whose artefacts the Neolithic Mondsee Culture (ca. 5650-5050 cal. yr BP, Ruttkay et al., 2004) has been named, is located close to the lake outlet Seeache. Sedimentological and pollen analyses of a sediment core from the lake outlet (Schmidt, 1986) indicate the presence of a cultural horizon, which is palynologically dated to the Younger Atlantic. This cultural horizon with abundant land use indicators is underlain 

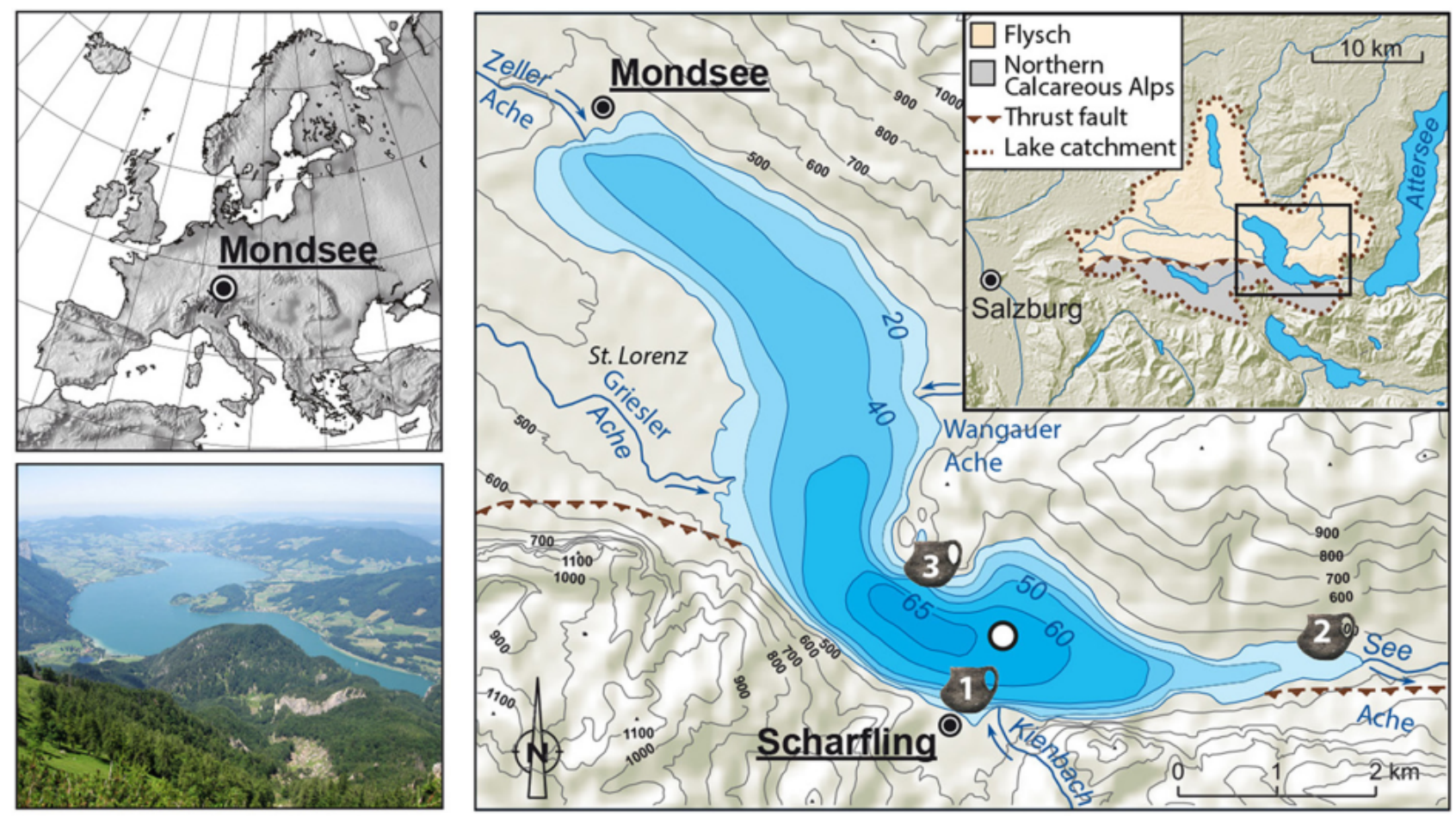

Fig. 1. Bathymetry of Lake Mondsee (water depth below lake level), relief with isobaths and simplified geological map of the lake catchment. Three main rivers (Griesler Ache, Wangauer Ache and Zeller Ache) and the small creek Kienbach are the main sources of detrital input. The locations of the three Neolithic lake-dwelling sites are indicated by Arabic numerals (1 - "Scharfling", 2 - "See", 3 - "Mooswinkel"). The coring site is shown by a white point.

by a clastic layer containing reworked/washed away material from pre-historic houses, which has been dated to $4720 \pm 110{ }^{14} \mathrm{C}$ yr BP (5659-5054 cal. yr BP, Schmidt, 1986). This age is in good agreement with conventional radiocarbon dates obtained from wooden artefacts from the Neolithic lake dwellings at the site "See", dating between $4910 \pm 130$ and $4660 \pm 80{ }^{14} \mathrm{C}$ yr BP (5920-5325 and 55895062 cal. yr BP, Table 1, Felber, 1970, 1985). The two other lake-dwelling sites "Scharfling" and "Mooswinkel" are located at the southern and northern shoreline of the lake, respectively. While remnants from the site "Scharfling", which is located ca. $3.5 \mathrm{~km}$ west of the site "See", are dated to the almost similar time interval as those from site "See", namely between $4940 \pm 120$ and $4660 \pm 90{ }^{14} \mathrm{C}$ yr BP (5931-5331 and 5590-5054 cal. yr BP, Table 1, Felber, 1974; Dworsky and Reitmaier, 2004), the site "Mooswinkel" on the northern shore is slightly younger and dates between $4560 \pm 100$ and $4260 \pm 90{ }^{14} \mathrm{C}$ yr BP (5576-4883 and 5213-4525 cal. yr BP, Table 1, Felber and Pak, 1973; Felber, 1975).

No younger than Neolithic lake dwellings have been discovered at Lake Mondsee so far (Ruttkay et al., 2004), while at other lakes in the European Alps, including adjacent Lake Attersee, the existence of lake dwellings until the Early and Middle Bronze Age (ca. 4200-3250 cal. yr BP) has been proven by archaeological and palaeobotani- cal studies (e.g. Magny, 1993; Menotti, 2004; Ruttkay et al., 2004; Billaud and Marguet, 2005; de Marinis et al., 2005; Pétrequin et al., 2005; Magny et al., 2009). The widely observed decline of lake dwellings in the Alpine region during the Late Neolithic has been related to a climatic deterioration towards wetter conditions, probably aggravated by socioeconomic changes (Magny, 2004; Menotti, 2009). However, an attention-grabbing article in a popular magazine recently suggested a single catastrophic rock fall event of $50 \times 10^{6} \mathrm{~m}^{3}$ close to the outlet of Lake Mondsee and a subsequent tsunami as a likely cause for the abrupt abandonment of the lake dwellings at Lake Mondsee (Schulz, 2008). Although this hypothesis can be clearly rejected from an archaeological perspective (Breitwieser, 2010; Offenberger, 2012), previous investigations on the morphology of the lake and the catchment close to the outlet provided indeed evidence for landslide deposits in the riverbed connecting Lake Mondsee and Lake Attersee (Janik, 1969). Nevertheless, the exact timing of these deposits and particularly the proposed connection to the abandonment of the Neolithic lake dwellings still remain unclear. Hence, our study presents an investigation of changes in flood frequencies reconstructed from the lake sediments, aiming at unravelling potentially influencing factors for the decline of the Neolithic Mondsee Culture. 
Table 1. Radiocarbon dates obtained from remnants of Neolithic lake dwellings in Lake Mondsee. Conventional ${ }^{14} \mathrm{C}$ ages (Felber and Pak, 1973; Felber, 1970, 1974, 1975, 1985; Dworsky and Reitmaier, 2004) were calibrated using OxCal 4.1 (Ramsey, 1995, 2001, 2009) with the IntCal09 calibration data set (Reimer et al., 2009).

\begin{tabular}{lllrr}
\hline Sample & Location & Dated material & $\begin{array}{r}\text { Conventional }{ }^{14} \text { C } \\
\text { age }\left({ }^{14} \text { C yr BP } \pm \sigma \text { ) }\right.\end{array}$ & $\begin{array}{r}\text { Calibrated age } \\
\text { (cal. yr BP, 2 } \sigma \text { range) }\end{array}$ \\
\hline VRI-250 & Mooswinkel & pile from lake dwelling (probably Populus) & $4560 \pm 100$ & $5576-4883$ \\
VRI-331 & Mooswinkel & pile from lake dwelling (Picea abies) & $4350 \pm 90$ & $5294-4657$ \\
VRI-332 & Mooswinkel & pile from lake dwelling (Picea abies) & $4260 \pm 90$ & $5213-4525$ \\
VRI-333 & Mooswinkel & pile from lake dwelling (Picea abies) & $4430 \pm 110$ & $5445-4826$ \\
VRI-311 & Scharfling & pile from lake dwelling (Picea abies) & $4940 \pm 120$ & $5931-5331$ \\
VRI-312 & Scharfling & pile from lake dwelling (Acer pseudoplatanus) & $4870 \pm 100$ & $5891-5326$ \\
VRI-313 & Scharfling & pile from lake dwelling (Fagus sylvatica) & $4660 \pm 90$ & $5590-5054$ \\
VRI-314 & Scharfling & pile from lake dwelling (Picea abies) & $4780 \pm 90$ & $5707-5312$ \\
ETH-26951 & Scharfling & pile from lake dwelling (Picea abies) & $4760 \pm 60$ & $5597-5324$ \\
ETH-26952 & Scharfling & pile from lake dwelling (Picea abies) & $4875 \pm 60$ & $5743-5472$ \\
ETH-26953 & Scharfling & pile from lake dwelling (Picea abies) & $4970 \pm 60$ & $5891-5596$ \\
VRI-823 & See & pile from lake dwelling (undetermined) & $4660 \pm 80$ & $5589-5062$ \\
VRI-37 & See & pile from lake dwelling (undetermined) & $4910 \pm 130$ & $5920-5325$ \\
VRI-68 & See & pile from lake dwelling (undetermined) & $4750 \pm 90$ & $5653-5306$ \\
VRI-119 & See & pile from lake dwelling (undetermined) & $4800 \pm 90$ & $5714-5319$ \\
\hline
\end{tabular}

\section{Methods}

\subsection{Fieldwork}

Two overlapping piston cores and three short gravity cores were retrieved from the southern basin of Lake Mondsee (coring site at $47^{\circ} 48^{\prime} 41^{\prime \prime} \mathrm{N}, 13^{\circ} 24^{\prime} 09^{\prime \prime} \mathrm{E}$; $62 \mathrm{~m}$ water depth; Fig. 1) in June 2005 within the frame of the ESF EuroCLIMATE project DecLakes by using UWITEC coring devices. All cores were opened, photographed and lithostratigraphically described on-site in a specially installed field lab. The $2 \mathrm{~m}$-long segments of the two piston cores and the gravity cores were then visually correlated by using distinct lithological marker layers, resulting in a ca. $15 \mathrm{~m}$-long continuous composite profile, which covers the complete Holocene and Late Glacial sedimentation history of Lake Mondsee (for further details see Lauterbach et al. (2011). The completeness of the detrital layer record in the core recovered from $62 \mathrm{~m}$ water depth and thus $6 \mathrm{~m}$ above the deepest part has been proven by detailed micro-stratigraphic comparison of short cores from both locations (Swierczynski et al., 2013).

\subsection{Sediment microfacies analysis and microscopic varve counting}

A continuous set of large-scale petrographic thin sections was prepared from a series of overlapping $10 \mathrm{~cm}$ long sediment blocks taken from the sediment cores of the composite profile, following the method described by Brauer and Casanova (2001). Thin sections were examined for detailed sediment microfacies analysis under a ZEISS Axiophot polarisation microscope at $25-200 \times$ magnification. In addi- tion, aiming at establishing a varve chronology for the Lake Mondsee sediments, continuous microscopic varve counting and thickness measurements were carried out in the distinctly laminated uppermost part of the Holocene sediment record $(0-610 \mathrm{~cm})$, whereas for the lowermost part $(610-1129 \mathrm{~cm})$ a varve-based sedimentation rate chronology was established. A detailed description of the microfacies of the Lake Mondsee sediments and the development of the Holocene varve chronology is given by Lauterbach et al. (2011). The present study focuses on the interval between 585 and $840 \mathrm{~cm}$ composite depth of the Lake Mondsee sediment record. Within this interval, intercalated detrital layers were counted and their thickness was measured. For testing the statistical significance of detrital layer occurrence and a better visual comparison with other proxy records a Kernel regression with bandwidths of 30 and $500 \mathrm{yr}$ (Mudelsee et al., 2003; Swierczynski et al., 2013) was applied to the data set.

\subsection{Radiocarbon dating and calibration}

The varve chronology for the Holocene part of the Lake Mondsee sediment record was further constrained by ${ }^{14} \mathrm{C}$ dating. For this purpose, terrestrial plant macrofossils (leaf fragments, seeds, bark) found in the sediments (Table 2) were dated by accelerator mass spectrometry (AMS) ${ }^{14} \mathrm{C}$ dating at the Leibniz Laboratory for Radiometric Dating and Stable Isotope Research in Kiel. All conventional radiocarbon ages were calibrated using OxCal 4.1 (Ramsey, 1995, 2001, 2009) with the IntCal09 calibration data set (Reimer et al., 2009). In order to ensure comparability and to evaluate possible relationships between Neolithic settlement activities along the shores of Lake Mondsee and climatic events recorded in the 
sediment core, previously published conventional radiocarbon dates from archaeological findings from the three local lake-dwelling sites (Table 1, Felber and Pak, 1973; Felber, 1970, 1974, 1975, 1985, Dworsky and Reitmaier, 2004) were carefully reviewed and also calibrated with OxCal 4.1 (Ramsey, 1995, 2001, 2009) using IntCal09 (Reimer et al., 2009). All calibrated ages are reported as $2 \sigma$ probability ranges.

\subsection{Geochemical analyses}

Semi-quantitative $\mu \mathrm{XRF}$ major element scanning was carried out at $200 \mu \mathrm{m}$ resolution on impregnated sediment slabs from thin section preparation between 585 and $736 \mathrm{~cm}$, using a vacuum-operating Eagle III XL micro X-ray fluorescence ( $\mu \mathrm{XRF}$ ) spectrometer with a low-power Rh X-ray tube at $40 \mathrm{kV}$ and $300 \mathrm{~mA}(250 \mathrm{~mm}$ spot size, $60 \mathrm{~s}$ counting time, single scan line). Element intensities for $\mathrm{Mg}, \mathrm{Al}$ and $\mathrm{Ca}$ are expressed as counts $\mathrm{s}^{-1}$ (cps), representing relative changes in element composition. The scanned sediment surfaces are identical to those prepared for thin sections, thus enabling a detailed comparison of high-resolution $\mu \mathrm{XRF}$ and sediment microfacies data (Brauer et al., 2009).

\section{Results}

\subsection{Chronology of the sediment record and dating of the Neolithic lake dwellings}

The varve chronology for the studied sediment interval (red line in Fig. 2) has been adopted from Lauterbach et al. (2011) with a slight change. According to a second independent varve count from present day back to 3878 vyr BP, 7 varves had to be subtracted from the original Lauterbach et al. (2011) chronology. The resulting varve chronology for the study interval has been confirmed by independent AMS ${ }^{14} \mathrm{C}$ dating (Fig. 2). A Bayesian age model with a P_Sequence deposition model (the model parameter $k$ was set to 1 ) implemented in OxCal 4.1 (Ramsey, 2008) has been established on the base of eleven AMS ${ }^{14} \mathrm{C}$ dates (Table 2). To avoid model inconsistencies such as unrealistically high uncertainty ranges at the upper and lower boundaries of the modelled interval, which usually occur when there are no radiocarbon dates, we chose a larger interval for ${ }^{14} \mathrm{C}$-based age modelling (ca. $550-950 \mathrm{~cm}$ ) than that actually under investigation (ca. $840-585 \mathrm{~cm}$ ). The agreement index $A_{\text {model }}$ of $69.1 \%$ for the resulting age-depth-model is fairly above the critical threshold of $60 \%$, proving the robustness of the model (Ramsey, 1995, 2001). Comparison of the varve- and radiocarbon-based age models reveals that both are statistically indistinguishable within their uncertainty ranges in the interval under investigation, supporting the robustness of the original varve chronology, which henceforth is used as the chronological framework for the sediment-derived proxy data.

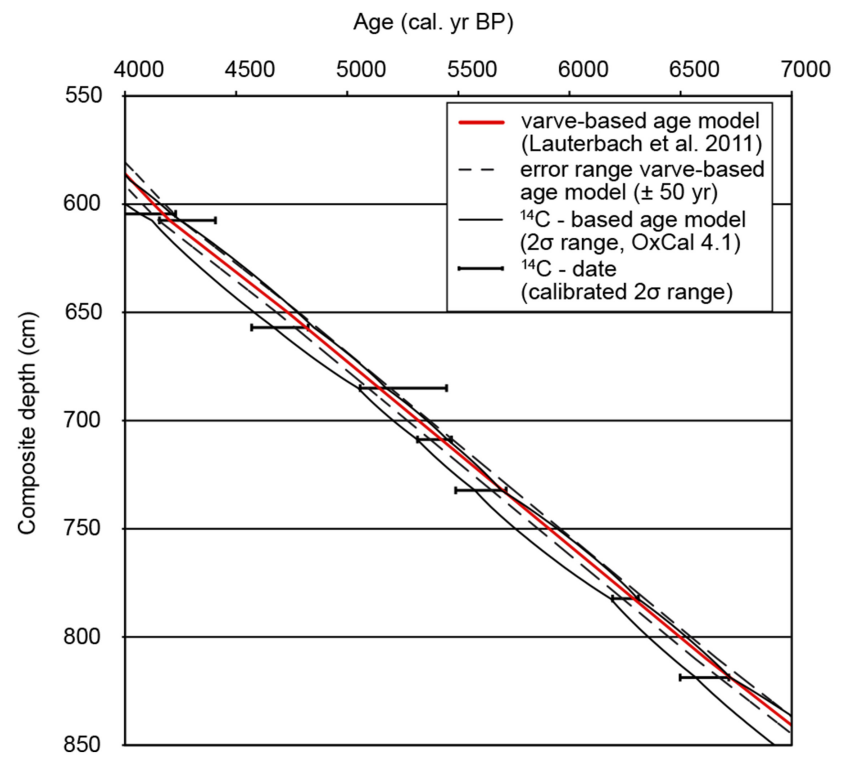

Fig. 2. Comparison of the primary varve-based age model (given with a counting uncertainty of $\pm 50 \mathrm{yr}$ as dashed lines) of the Lake Mondsee record (Lauterbach et al., 2011) and a secondary radiocarbon-based age model ( $2 \sigma$ probability range in grey), which has been established using OxCal 4.1 (Ramsey, 1995, 2001, 2008) to evaluate the reliability of the varve chronology. Individual AMS ${ }^{14} \mathrm{C}$ dates from terrestrial plant macrofossils, which are included in the radiocarbon-based age model are given with their $2 \sigma$ probability ranges.

The chronology of the Neolithic settlements at Lake Mondsee has been established on the base of 15 published conventional radiocarbon dates (Table 1, Felber and Pak, 1973; Felber, 1970, 1974, 1975, 1985; Dworsky and Reitmaier, 2004), which were obtained from wooden artefacts recovered from the three subaquatic lake-dwelling sites during previous archaeological surveys. In order to assess the time interval during which the individual lake-dwelling sites existed (in the following termed settlement period), these dates were used as input parameters for a Phase model implemented in OxCal 4.1 (Ramsey, 2009). As a result, the two settlements "Scharfling" and "See" on the southeastern and southern lake shore apparently existed almost contemporaneously (Fig. 3) from $5645 \pm 149$ to $5513 \pm 90$ cal. yr BP and from $5458 \pm 113$ to $5396 \pm 146$ cal. yr BP, respectively, constituting a first settlement period (SP I, Fig. 3). From these dates, a maximum duration of $544 \mathrm{yr}$ (5794-5250 cal. yr BP) is inferred for SP I. A more precise assessment is impeded by the rather large error ranges of the radiocarbon dates. In contrast, the site "Mooswinkel" appears to have been established slightly later (ca. $5144 \pm 230$ cal. yr BP), when the two other sites apparently were already abandoned, thus representing a second settlement period (SP II). The demise of this settlement period is dated to $4982 \pm 296 \mathrm{cal}$. yr BP resulting in a maximum duration of about $688 \mathrm{yr}$ (5374-4686 
Table 2. Selected AMS ${ }^{14} \mathrm{C}$ dates obtained from terrestrial macrofossils from the Lake Mondsee sediment core. All conventional ${ }^{14} \mathrm{C}$ ages were calibrated using the OxCal 4.1 program (Ramsey, 1995, 2001, 2009) with the IntCal09 calibration data set (Reimer et al., 2009). Sample KIA32795 was rejected from age modelling with OxCal. For a full account on radiocarbon dates from the Lake Mondsee sediment record and the primary varve-based age model see Lauterbach et al. (2011).

\begin{tabular}{|c|c|c|c|c|c|}
\hline Sample & $\begin{array}{l}\text { Composite } \\
\text { depth }(\mathrm{cm})\end{array}$ & Dated material & $\begin{array}{r}\text { Carbon content } \\
(\mathrm{mg}) \delta^{13} \mathrm{C} \pm \sigma(\% \circ)\end{array}$ & $\begin{array}{l}\text { AMS }{ }^{14} \mathrm{C} \text { age } \\
\quad(\mathrm{yr} \mathrm{BP} \pm \sigma)\end{array}$ & $\begin{array}{r}\text { Calibrated age } \\
\text { (cal. yr BP, } 2 \sigma \text { range) }\end{array}$ \\
\hline KIA36610 & 589.00 & plant remains ${ }^{b}$ & $2.22 /-27.03 \pm 0.25$ & $3618 \pm 33$ & $4070-3839$ \\
\hline KIA36611 & 604.50 & plant remains ${ }^{b}$ & $0.41 /-29.03 \pm 0.36$ & $3697 \pm 56$ & $4228-3880$ \\
\hline KIA29395 & 607.50 & plant remains ${ }^{b}$ & $4.06 /-29.21 \pm 0.04$ & $3848 \pm 26$ & $4407-4155$ \\
\hline KIA39229 & 657.00 & leaves ${ }^{\mathrm{a}}$ & $1.61 /-28.99 \pm 0.09$ & $4142 \pm 31$ & $4824-4570$ \\
\hline KIA39230 & 685.00 & leaves ${ }^{\mathrm{a}} \&$ needle & $2.28 /-28.77 \pm 0.12$ & $4581 \pm 34$ & $5447-5058$ \\
\hline KIA32793 & 708.75 & twig \& bark & $4.89 /-28.60 \pm 0.05$ & $4668 \pm 28$ & $5566-5316$ \\
\hline KIA36612 & 732.25 & wood \& leaves & $0.97 /-27.69 \pm 0.13$ & $4883 \pm 41$ & $5715-5488$ \\
\hline KIA32794 & 782.25 & leaves ${ }^{\mathrm{a}}$ & $1.04 /-30.09 \pm 0.15$ & $5462 \pm 36$ & $6310-6194$ \\
\hline KIA36619 & 818.75 & plant remains ${ }^{b}$ & $1.65 /-26.55 \pm 0.13$ & $5809 \pm 36$ & $6717-6498$ \\
\hline KIA32795 & 873.00 & plant remains ${ }^{b}$ & $0.28 /-32.70 \pm 0.23$ & $6088 \pm 104$ & $7246-6727$ \\
\hline KIA32796 & 916.50 & leaves $^{\mathrm{a}}$ & $3.29 /-29.61 \pm 0.09$ & $7129 \pm 36$ & $8014-7869$ \\
\hline KIA39231 & 941.00 & twig & $0.95 /-29.41 \pm 0.12$ & $7349 \pm 48$ & $8311-8026$ \\
\hline
\end{tabular}

${ }^{a}$ Undetermined terrestrial leaf fragments. ${ }^{b}$ Various undetermined terrestrial plant remains (leaves, wood, seeds).

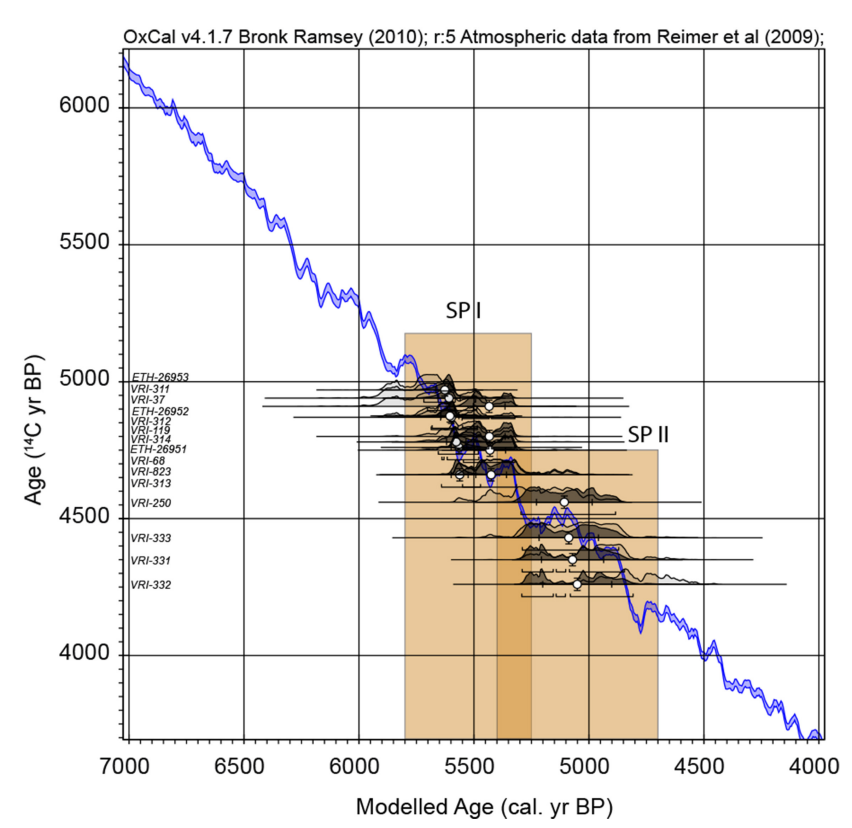

Fig. 3. Chronology of settlement periods at Lake Mondsee. Twelve published AMS radiocarbon dates from three Neolithic lakedwelling sites ("See", "Scharfling" and "Mooswinkel") were calibrated and used as input parameters for period modelling with OxCal 4.1 (Ramsey, 2009). Two different settlement periods can be distinguished: SP I from ca. 5800 to $5250 \mathrm{cal}$. yr BP and SP II from ca. 5400 to $4700 \mathrm{cal}$. yr BP.

cal. yr BP). Also for this settlement period we cannot exclude a much shorter duration because of the large dating errors. Dendrochronological dating of the wooden artefacts to further narrow the settlement periods was not successful because the discovered tree-ring series were too short and regional tree-ring chronologies are still missing to allow a robust wiggle matching (Dworsky and Reitmaier, 2004).

\subsection{Sediment microfacies and geochemical properties}

The Holocene sediments of Lake Mondsee are composed of calcite varves (Schmidt, 1991; Lauterbach et al., 2011) with frequently intercalated detrital layers. As revealed from $\mu \mathrm{XRF}$ data, the light sub-layers are enriched in $\mathrm{Ca}$ (Fig. 3), resulting from endogenic calcite precipitation after spring/summer algae bloom. In contrast, the dark sublayers are enriched in elements like Ti, indicative for siliciclastic material and reflecting clastic sediment deposition during autumn/winter. Two types of detrital layers can be distinguished within the Lake Mondsee sediments (Swierczynski et al., 2012). Thick $(0.9-32.0 \mathrm{~mm})$ and mainly graded detrital layers reflect local debris flow events (detrital layer type 2). The enrichment of $\mathrm{Mg}$ in the type 2 detrital layers, indicative for dolomitic rocks, and low contents of siliciclastic elements (e.g. Ti) reveal the Northern Calcareous Alps as the source region. In contrast, thin detrital layers $(0.05-$ $1.7 \mathrm{~mm}$ ) are non-graded and composed of both, siliciclastic and dolomitic components (detrital layer type 1), thus revealing sediment delivery from both the northern and southern part of the catchment by regional-scale flood events. Detrital layers from flood events reveal a higher abundance and also increased thicknesses between 800 and $665 \mathrm{~cm}$, whereas for debris flow-related layers no clear clustering can be observed. Increased $\mathrm{Ti}$ counts characterise the interval between 715 and $670 \mathrm{~cm}(5490-4961 \mathrm{vyr} \mathrm{BP})$, whereas $\mathrm{Mg}$ is enriched between 665 and $630 \mathrm{~cm}$ (4902-4475 vyr BP) (Fig. 4). 


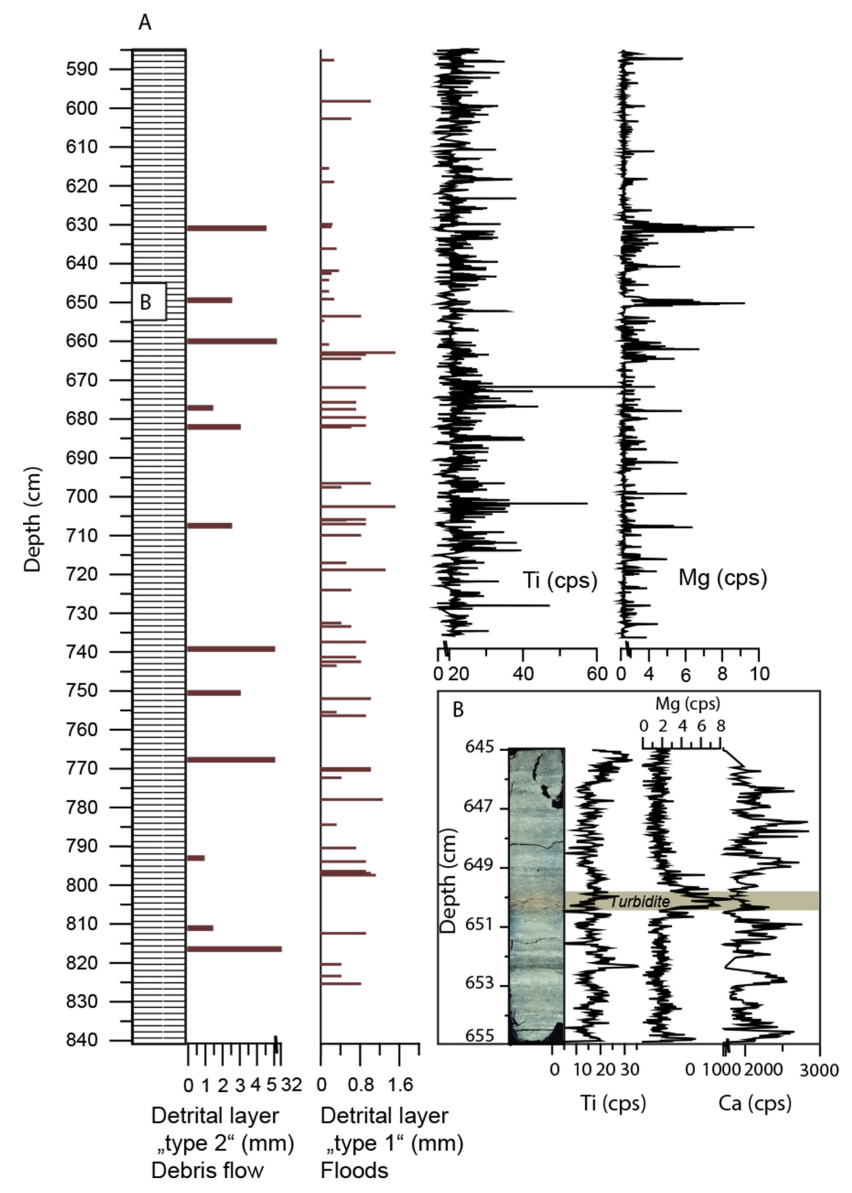

Fig. 4. Sediment data. (a) Lithology of the sediment core covering the interval between 585 and $840 \mathrm{~cm}$ with complementing detrital layer record (for further explanations see the main text), results of magnetic susceptibility measurements and $\mu$ XRF element scanning data for titanium ( $\mathrm{Ti}$ ) and magnesium $(\mathrm{Mg})$ for the interval between 585 and $736 \mathrm{~cm}$. (b) Sediment microfacies as revealed from a thin section $(645-655 \mathrm{~cm})$ with a turbidite (detrital layer type 1) and corresponding $\mu \mathrm{XRF}$ data for $\mathrm{Ti}, \mathrm{Mg}$ and $\mathrm{Ca}$.

\subsection{Flood and debris flow deposition}

By combining sediment microfacies and geochemical analyses, a total of 60 flood and 12 debris flow layers could be detected within the investigated interval between 840 and $585 \mathrm{~cm}$ composite depth (ca. $7000-4000$ vyr BP; Fig. 5). The mean recurrence of floods during this $3000 \mathrm{yr}$ interval is ca. $67 \mathrm{yr}$ but increases by a factor of about seven during episodes of increased flood frequencies. Debris flows have a mean recurrence interval of ca. $333 \mathrm{yr}$ during the investigated time interval. Although anthropogenic land use is commonly regarded to influence erosion processes in the catchment, detrital layer deposition in Lake Mondsee has been shown to be mainly climate-controlled, even during recent times when human impact in the catchment was likely much more intense than during the Neolithic (Swierczynski et al., 2013).

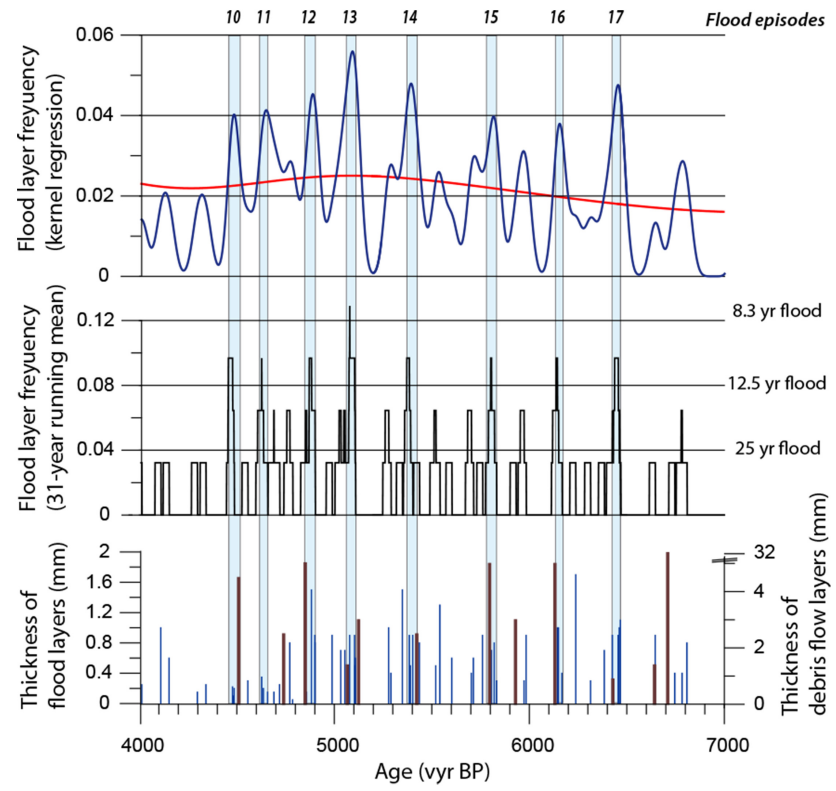

Fig. 5. Thickness of debris flow (detrital layer type 1) and flood layers (detrital layer type 2). Flood layer frequency as calculated by a 31 yr running mean and kernel regression with different bandwidths (blue line: $30 \mathrm{yr}$, red line: $500 \mathrm{yr}$ ). Eight main flood intervals (FE 10 to FE 17) are identified according to multi-decadal flood recurrence.

On a multi-centennial to millennial timescale (kernel bandwidth of $500 \mathrm{yr}$ ), the flood activity is highest (mean flood recurrence of 40-50 yr) between ca. 5900 and $4450 \mathrm{vyr}$ $\mathrm{BP}$ in the interval under investigation (Fig. 5). By using a kernel bandwidth of $30 \mathrm{yr}$, eight distinct episodes of increased flood frequency FE 10 to FE 17 (flood episodes FE 1 to FE 9 during the period younger than ca. $4000 \mathrm{vyr}$ BP are described in detail in Swierczynski et al. (2012, 2013)), each of ca. $50 \mathrm{yr}$ duration can be been identified in the Neolithic Lake Mondsee sediment record: FE 10 (4450-4500 vyr BP), FE 11 (4620-4670 vyr BP), FE 12 (4850-4900 vyr BP), FE 13 (5040-5110 vyr BP), FE 14 (5360-5410 vyr BP), FE 15 (5800-5850 vyr BP), FE 16 (6120-6170 vyr BP) and FE 17 (6420-6470 vyr BP). The $31 \mathrm{yr}$ running mean of flood frequencies reveals flood recurrence rates of $\sim 10 \mathrm{yr}$ during these episodes. The occurrence of major multi-decadal flood episodes with flood recurrence rates of $10-16 \mathrm{yr}$ is clearly lower prior to $5900 \mathrm{vyr}$ BP (two flood episodes FE 16 and 17) compared to the time interval between 5900 and $4450 \mathrm{vyr}$ $\mathrm{BP}$, which is characterised by six of such flood episodes (FE 10 to 15 ). Particularly the interval between ca. 5150 and $4450 \mathrm{vyr}$ BP is characterised by frequent flood episodes (four FE within ca. $700 \mathrm{yr})$ with high flood recurrence $(<10 \mathrm{yr})$. The period younger than ca. $4450 \mathrm{vyr}$ BP shows, compared to the interval 5900-4450 vyr BP, a relatively low flood activity with recurrence rates of $30 \mathrm{yr}$ or more. 


\section{Discussion}

According to Phase modelling with OxCal 4.1 (Ramsey, 2009) for the available radiocarbon dates from the three archaeological sites at Lake Mondsee, two time intervals can be distinguished during which the Neolithic settlements most likely existed. The first settlement period (SP I; Fig. 3), including the sites "Scharfling" and "See" at the southern and southeastern shores of Lake Mondsee, occurred for some time in between ca. 5800 and 5250 cal. yr BP while the "Mooswinkel" settlement at the northern shore (SP II) existed in between ca. 5400 and 4700 cal. yr BP. In addition to the apparent chronological succession, both settlement periods are characterised by different construction techniques. While the lake dwellings of SP I were constructed on the wetlands with the basement of the houses being probably only ca. $20-30 \mathrm{~cm}$ above the ground (Ruttkay, 2003), those of SP II were built on piles, indicative for buildings standing in the water (Offenberger, 1986, 2012; Ruttkay, 2003). The already mentioned large error ranges of the radiocarbon dates do not allow to unequivocally distinguish between the construction of the lake dwellings (time when the trees were cut) and their abandonment; in addition, dendrochronological investigations so far yielded no results to better constrain the age of the Neolithic lake dwellings at Lake Mondsee (Dworsky and Reitmaier, 2004). However, it is very likely that these buildings did not exist longer than a few decades before they were repaired or replaced by new ones (Schlichtherle, 2004) Although the uncertainties in the available archaeological dating hamper a precise comparison to the high-resolution decadal-scale flood data, we still consider the comparison with centennial-scale climate and flood data a worthwhile and meaningful approach.

Pollen (Bortenschlager, 1970), tree-line (Nicolussi et al., 2005), lake level (Magny, 2004) and glacier records (Holzhauser et al., 2005; Holzhauser, 2007; Ivy-Ochs et al., 2009) indicate that the generally warmer and drier climate in the Central Alps between ca. 10500 and 3300 cal. yr BP (Ivy-Ochs et al., 2009) was punctuated by several intervals of climate deterioration. In this context, the slight increase in centennial-scale flood variability at Lake Mondsee after ca. 6500 vyr BP and particularly the more pronounced clustering of flood events after ca. $5900 \mathrm{vyr}$ BP are in good agreement with a phase of wetter and colder climate conditions in the Alps between 6300 and $5500 \mathrm{cal}$. yr BP, the Rotmoos I cold oscillation (Bortenschlager, 1970; Patzelt, 1977). Also the peaking flood activity in Lake Mondsee around $5100 \mathrm{vyr}$ $\mathrm{BP}$ is synchronous to a regional-scale cold/wet period, the Rotmoos II oscillation (Bortenschlager, 1970; Patzelt, 1977) from ca. 5400 to $5000 \mathrm{cal}$. yr BP. The regional significance of this short-term climate deterioration is also reflected by the burial of the Neolithic ice man from the Similaun by advancing glaciers, dated to ca. 5300-5050 cal. yr BP (Bonani et al., 1994; Baroni and Orombelli, 1996). Increased precipitation and lake-level highstands during these intervals and possi- ble consequences for Neolithic lake dwellings have also been reported from other sites in Switzerland, Italy and France (Magny, 2004; Magny et al., 2006). Increased flood activity at Lake Mondsee between ca. 5900 and 4450 vyr BP is furthermore in good correspondence with cold and wet climate conditions reported from the Austrian Central Alps for the periods between 5800 and $5400 \mathrm{cal}$. yr BP and around 5100 cal. yr BP (Schmidt et al., 2006, 2009). Interestingly, similar increases in flood activity during times when climate became cooler in the Lake Mondsee region have also reported for the last $1600 \mathrm{yr}$, e.g. during the Dark Ages Cold Period and the transition into the Little Ice Age (Swierczynski et al., 2012). A drier episode around $5200 \mathrm{cal}$. yr BP in the Central Austrian Alps (Schmidt et al., 2009) might be reflected by the period of low flood recurrence in Lake Mondsee between FE 13 and 14.

Since flood-related lake-level changes of up to $2.5 \mathrm{~m}$ within a few days have been observed at Lake Mondsee during the last century (Swierczynski et al., 2009), the lake dwellings "Scharfling" and "See", both constructed directly on the southern wetland plains, are expected to have been particularly vulnerable to the overall increase in flood risk at Lake Mondsee after ca. 5900 vyr BP. However, both lakedwelling sites existed even during this interval, which culminated during FE 14 around 5400 vyr BP (Fig. 6), and beyond. The abandonment of the SP I lake dwellings "Scharfling" and "See" apparently only occurred around $5250 \mathrm{cal}$. yr BP, during an interval of relatively low flood risk after FE 14. This makes a causal relation between increased flood risk and both the change in the settlement location and the construction type unlikely. However, it cannot be fully excluded due to the given uncertainties of the archaeological datings. In addition to flood risk, both settlements must also have been vulnerable to the effects of hydrologically triggered surface erosion processes, i.e. debris flows after strong precipitation events, as they were located close to the steep slopes of the Northern Calcareous Alps (maximum slope of $34 \%$ in the Kienbach valley and cascades of up to $60 \mathrm{~m}$ close to the settlement "Scharfling"), which are the source of local debris flows. Such erosion events are documented for recent times (Swierczynski et al., 2009) and also occurred during the Neolithic settlement period (Fig. 5), but as there is neither a significant clustering of debris flows around the time of the abandonment of the lake dwellings at the southern shores of Lake Mondsee nor throughout the entire investigated record, a causal connection between both is unlikely. In summary, there is no clear indication that either increased flood risk or debris flow activity led to an abandonment of the SP I lake dwellings. The possibility of lake-level fluctuations as a cause for the demise of these settlements (Schmidt, 1986) also remains elusive.

Despite the evidence for significant climatic changes in the Alpine region during the second half of the fourth millennium BC and an apparently corresponding increase in flood risk at Lake Mondsee, the contemporaneous abandonment 
of the lake-dwelling sites "Scharfling" and "See", and the subsequent shift of Neolithic settlement activity to the northern shore of Lake Mondsee is not necessarily attributable to climatic changes. This is corroborated by the fact that the onset of SP II at the site "Mooswinkel" even falls within an interval of increased flood activity (flood episodes FE 11, 12 and 13). Although the characteristic construction of the "Mooswinkel" buildings on piles and the shift in the location might be looked upon as an adaptation to increased flood risk, archaeological investigations indicate that these lake dwellings have rather been constructed for a special purpose (a ferry landing, Ruttkay et al., 2004). Furthermore, despite generally low flood frequencies after $4450 \mathrm{vyr}$ BP, there is no indication for a re-appearance of lake-shore settlements after the end of SP II. Hence, the abandonment of the lake dwellings of the Mondsee Culture was likely not caused by climate change and related flood risks alone but rather by a more complex interplay of climatic and socio-cultural changes (Magny, 2004) and/or a change in the subsistence strategy (Menotti, 2003, 2009), e.g. hinterland migration or the beginning of alpine pasturing during the Late Neolithic (Bortenschlager and Oeggl, 2000).

Alternatively, a single catastrophic rockfall event has also been proposed to have caused the abrupt abandonment of the lake dwellings, at least at the southern shores of Lake Mondsee (Schulz, 2008). However, in contrast to the hypothesis of increased flood risk or lake-level changes, such a catastrophic event can be very likely rejected as the cause for the decline of the Neolithic Mondsee Culture from archaeological evidence (Breitwieser, 2010; Offenberger, 2012). In addition, no indication for an event layer caused by a large rockfall/landslide event has been found in the entire sediment record from Lake Mondsee, even with precise microfacies techniques allowing very detailed analyses of sediment structures. Since such an event must have supplied large amounts of suspended detrital material into the lake, it should be reflected by the deposition of a turbiditic event layer of outstanding thickness in the sediment record as shown for earthquake-related (Chapron et al., 1999; Fanetti et al., 2008; Lauterbach et al., 2012) or gravitationally triggered masswasting deposits (Girardclos et al., 2007) in other lake sediment records. Particularly in the case of historically documented landslides and associated tsunamis, the basin-wide deposition of thick turbidites has been documented in Swiss lakes (Bussmann and Anselmetti, 2010; Kremer et al., 2012), but no such layer has been found in the Lake Mondsee record. The rejection of a catastrophic rockfall is further supported by systematic diving expeditions in 2003 and 2004, revealing no rock debris or unusual relief disturbances in the lake basin (Breitwieser, 2010). Also investigations on the settlement site at the southeastern shoreline did not report a tsunami-related event layer or any abnormal stratification above the Neolithic cultural horizon (Schmidt et al., 1986).

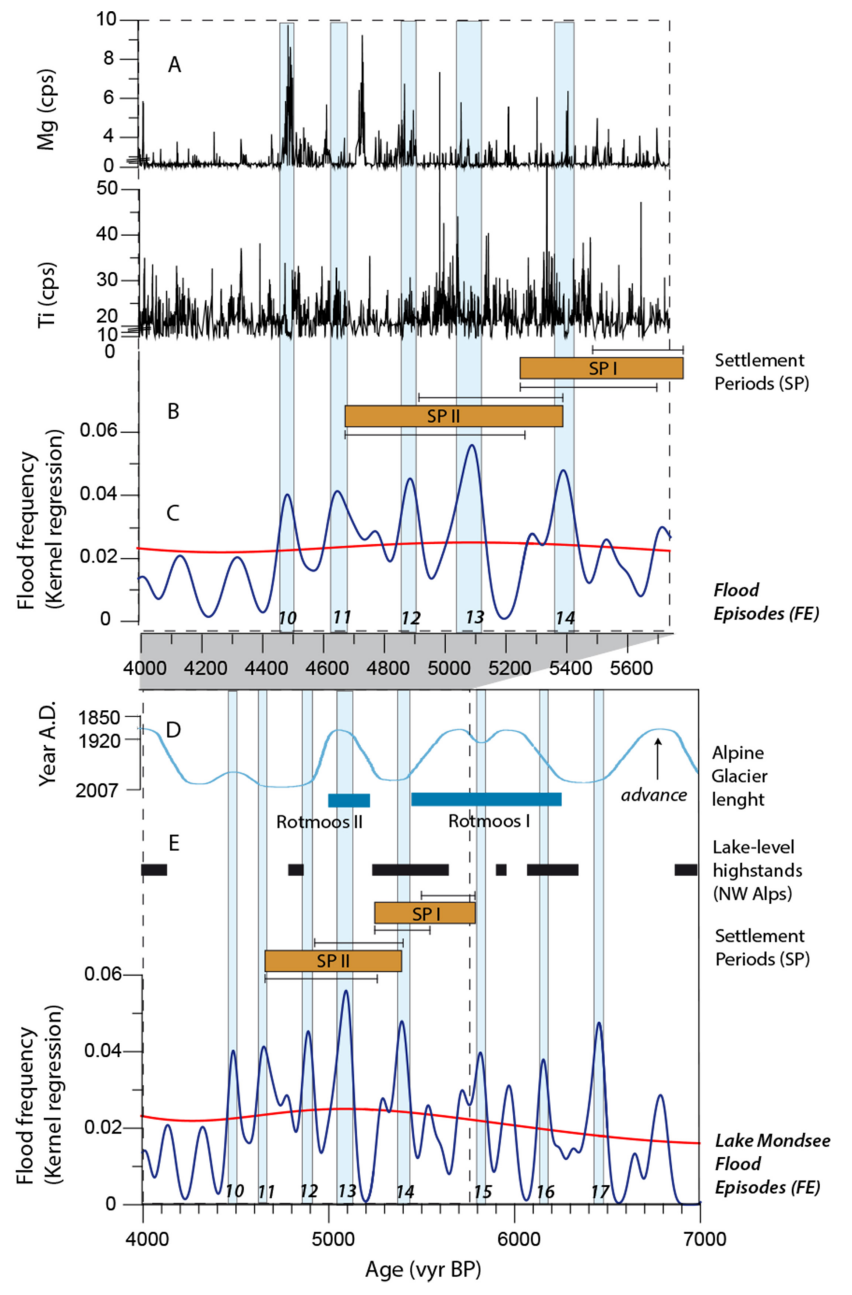

Fig. 6. Comparison of Lake Mondsee sediment data and identified flood episodes (FE 10 to FE 17) with other proxy data. (a) $\mu \mathrm{XRF}$ element scans for $\mathrm{Ti}$ and $\mathrm{Mg}$ from Lake Mondsee sediments. (b) Settlement periods SP I and SP II at Lake Mondsee (bars above and below the respective box indicate radiocarbon dates (as $2 \sigma$ uncertainty intervals) of the youngest and oldest artefacts from both settlement periods). (c) Flood occurrence at Lake Mondsee (Kernel regression with 30 (blue) and $500 \mathrm{yr}$ (red) bandwidth). (d) Alpine glacier lengths (Holzhauser, 2007) and phases of the Rotmoos Oscillation (Bortenschlager, 1970). (e) Lake-level highstands in the NW Alps (Magny, 2004).

\section{Conclusions}

We investigated the recurrence of extreme hydrometeorological events (local debris flows and regional floods) in the sediment record of Lake Mondsee (Upper Austria) during the interval of Neolithic settlement activity between 7000 and 4000 vyr BP. Six pronounced decadalscale intervals of increased flood activity occurred between ca. 5900 and $4450 \mathrm{vyr}$ BP. Increased flood risk at Lake Mondsee during this interval is in agreement with highly variable lake levels and also glacier advances during the 
Rotmoos cold oscillations, indicating colder and wetter climate conditions in the Alpine region. At some time within this time interval Neolithic settlement strategy changed from building lake dwellings on the wetlands at the southern and southeastern shores of Lake Mondsee (5800-5250 cal. yr $\mathrm{BP})$ to constructing lake dwellings on piles upon the water at the northern lake shore (5400-4700 cal. yr BP). However, the enhanced flood risk during this time is unlikely to be the only cause for this change in settlement strategy. More likely a combination of several factors including increased flood recurrence, a rising lake level and probably also socioeconomic changes was responsible for the observed shift in human settlement strategy. Also the final decline of the Mondsee Culture around 4700 cal. yr BP cannot be related solely to climatic changes as there were no new settlements built after ca. 4450 vyr BP when flood risk had decreased. In order to better understand the effects of high-frequency climate variability on pre-historic lake-dweller societies, additional ${ }^{14} \mathrm{C}$-dates with reduced uncertainties as well as more interdisciplinary research between archaeologists and palaeoclimatologists are necessary.

Acknowledgements. Lake coring was carried out within the frame of the European Science Foundation project DecLakes (EuroCLIMATE programme, 04-ECLIM-FP29), funded by the DFG (Deutsche Forschungsgemeinschaft) grants BR 2208/2-2 and AN554/1-2. The Institute for Limnology in Mondsee and the Institute for Water Ecology, Fisheries and Lake Research in Scharfling are acknowledged for their help during the coring campaign. This study is a contribution to the BMBF (German Federal Ministry of Education and Research) project PROGRESS (A3, Extreme events in Geoarchives; 03IS2191G). The data presented in the figures here are available at doi:10.5880/GFZ.5.2.2012.002 and via the PANGAEA network.

Edited by: F. Viehberg

The service charges for this open access publication have been covered by a Research Centre of the Helmholtz Association.

\section{References}

Baroni, C. and Orombelli, G.: The Alpine "Iceman" and Holocene climatic change, Quaternary Res., 46, 78-83, 1996.

Billaud, Y. and Marguet, A.: Habitats lacustres du Néolithique et de l'âge du Bronze dans les lacs alpins français: bilan des connaissances et perspectives, in: WES'04 - Wetland Economies and Societies - Collectio Archæologica 3, edited by: Della Casa, P. and Trachsel, M., Chronos, Zurich, 169-178, 2005.

Bonani, G., Ivy, S. D., Hajdas, I., Niklaus, T. R., and Suter, M.: AMS ${ }^{14} \mathrm{C}$ age determinations of tissue, bone and grass samples from the Ötztal ice man, Radiocarbon, 36, 247-250, 1994.

Bortenschlager, S.: Waldgrenz- und Klimaschwankungen im pollenanalytischen Bild des Gurgler Rotmooses, Mitteilungen der
Ostalpin-Dinarischen Gesellschaft für Vegetationskunde, 11, 1926, 1970.

Bortenschlager, S. and Oeggl, K.: The man in the ice. IV The iceman and his natural environemnt, Springer, Vienna, 1-164, 2000.

Brauer, A. and Casanova, J.: Chronology and depositional processes of the laminated sediment record from Lac d'Annecy, French Alps, J. Paleolimnol., 25, 163-177, 2001.

Brauer, A., Dulski, P., Mangili, C., Mingram, J., and Liu, J.: The potential of varves in high-resolution paleolimnological studies, PAGES News, 17, 96-98, 2009.

Breitwieser, R.: Der "Mondsee-Tsunami" - Fakt oder Mediengang?, in: Nachrichtenblatt Arbeitskreis Unterwasserarchäologie, edited by: Kommission für Unterwasserarchäologie im verband der Landesarchäologen in der Bundesrepublik Deutschland, 85-108, 2010.

Bussmann, F. and Anselmetti, F. S.: Rossberg landslide history and flood chronology as recorded in Lake Lauerz sediments (Central Switzerland), Swiss J. Geosci., 103, 43-59, 2010.

Chapron, E., Beck, C., Pourchet, M., and Deconinck, J. F.: 1822 earthquake-triggered homogenite in Lake Le Bourget (NW Alps), Terra Nova, 11, 86-92, 1999.

de Marinis, R. C., Rapi, M., Ravazzi, C., Arpenti, E., Deaddis, M., and Perego, R.: Lavagnone (Desenzano del Garda): new excavations and palaeoecology of a Bronze Age pile dwelling site in northern Italy, in: WES'04 - Wetland Economies and Societies Collectio Archæologica 3, edited by: Della Casa, P. and Trachsel, M., Chronos, Zurich, 221-232, 2005.

deMenocal, P. B.: Cultural responses to climate change during the late Holocene, Science, 292, 667-673, 2001.

Dworsky, C. and Reitmaier, T.: Moment, da war doch noch was! Neues zur Pfahlbauarchäologie im Mond- und Attersee 1854-2004: 150 Jahre Entdeckung der Pfahlbauten, Archäologie Österreichs, 15/2, 4-15, 2004.

Fanetti, D., Anselmetti, F. S., Chapron, E., Sturm, M., and Vezzoli, L.: Megaturbidite deposits in the Holocene basin fill of Lake Como (southern Alps, Italy), Palaeogeogr. Palaeocl., 259, $323-$ 340, 2008.

Fedele, F. G., Giaccio, B., and Hajdas, I.: Timescales and cultural process at 40,000 BP in the light of the Campanian Ignimbrite eruption, Western Eurasia, J. Human Evolut., 55, 834-857, 2008.

Felber, H.: Vienna Radium Institute radiocarbon dates I, Radiocarbon, 12, 298-318, 1970.

Felber, H.: Vienna Radium Institute radiocarbon dates V, Radiocarbon, 16, 277-283, 1974.

Felber, H.: Vienna Radium Institute radiocarbon dates VI, Radiocarbon, 17, 247-254, 1975.

Felber, H.: Vienna Radium Institute radiocarbon dates XV, Radiocarbon, 27, 616-622, 1985.

Felber, H. and Pak, E.: Vienna Radium Institute radiocarbon dates IV, Radiocarbon, 15, 425-434, 1973.

Girardclos, S., Schmidt, O. T., Sturm, M., Ariztegui, D., Pugin, A., and Anselmetti, F. S.: The 1996 AD delta collapse and large turbidite in Lake Brienz, Mar. Geol., 241, 137-154, 2007.

Haug, G. H., Günther, D., Peterson, L. C., Sigman, D. M., Hughen, K. A., and Aeschlimann, B.: Climate and the Collapse of Maya Civilization, Science, 299, 1731-1735, 2003.

Holzhauser, H.: Holocene glacier fluctuations in the Swiss Alps, in: Environnements et cultures à l'Âge du Bronze en Europe occidentale, edited by: Richard, H., Magny, M., and Mordant, C., 
Éditions du CTHS, Paris, 29-43, 2007.

Holzhauser, H., Magny, M., and Zumbühl, H. J.: Glacier and lakelevel variations in west-central Europe over the last 3500 years, The Holocene, 15, 789-801, 2005.

Ivy-Ochs, S., Kerschner, H., Maisch, M., Christl, M., Kubik, P. W., and Schlüchter, C.: Latest Pleistocene and Holocene glacier variations in the European Alps, Quaternary Sci. Rev., 28, $2137-$ 2149, 2009.

Jagsch, A. and Megay, K.: Mondsee, in: Seenreinhaltung in Österreich, edited by: Wurzer, E., Bundesministerium für Landund Forstwirtschaft, Wien, Wasserwirtschaft, 6, 155-163, 1982.

Janik, V.: Die Pfahlbausiedlung See/Mondsee im Blickfeld landschaftlicher Forschung, Jahrbuch des oberösterreichischen Musealvereines, 114a, 181-200, 1969.

Keller, F.: Die keltischen Pfahlbauten in den Schweizerseen, Mitteilungen der antiquarischen Gesellschaft in Zürich, 1, 65-101, 1854.

Klee, R. and Schmidt, R.: Eutrophication of Mondsee (Upper Austria) as indicated by the diatom stratigraphy of a sediment core, Diatom Research, 2, 55-76, 1987.

Kremer, K., Simpson, G., and Girardclos, S.: Giant Lake Geneva tsunami in AD 563, Nat. Geosci., 5, 756-757, 2012.

Lauterbach, S., Brauer, A., Andersen, N., Danielopol, D. L., Dulski, P., Hüls, M., Milecka, K., Namiotko, T., Obremska, M., von Grafenstein, U., and Declakes participants: Environmental responses to Lateglacial climatic fluctuations recorded in the sediments of pre-Alpine Lake Mondsee (northeastern Alps), J. Quaternary Sci., 26, 253-267, 2011.

Lauterbach, S., Chapron, E., Brauer, A., Hüls, M., Gilli, A., Arnaud, F., Piccin, A., Nomade, J., Desmet, M., von Grafenstein, U., and DecLakes Participants: A sedimentary record of Holocene surface runoff events and earthquake activity from Lake Iseo (Southern Alps, Italy), The Holocene, 22, 749-760, 2012.

Magny, M.: Un cadre climatique pour les habitats lacustres préhistoriques?, Comptes Rendus de l'Académie des Sciences, 316, 1619-1625, 1993.

Magny, M.: Holocene climate variability as reflected by midEuropean lake-level fluctuations and its probable impact on prehistoric human settlements, Quaternary Int., 113, 65-79, 2004.

Magny, M. and Haas, J. N.: A major widespread climatic change around 5300 cal. yr BP at the time of the Alpine Iceman, J. Quaternary Sci., 19, 423-430, 2004.

Magny, M., Leuzinger, U., Bortenschlager, S., and Haas, J. N.: Tripartite climate reversal in Central Europe 5600-5300 years ago, Quaternary Res., 65, 3-19, 2006.

Magny, M., Galop, D., Bellintani, P., Desmet, M., Didier, J., Haas, J. N., Martinelli, N., Pedrotti, A., Scandolari, R., Stock, A., and Vanniere, B.: Late-Holocene climatic variability south of the Alps as recorded by lake-level fluctuations at Lake Ledro, Trentino, Italy, The Holocene, 19, 575-589, 2009.

Menotti, F.: The "Pfahlbauproblem" and the history of lakedwelling research in the Alps, Oxford J. Archaeol., 20, 319-328, 2001.

Menotti, F.: Cultural response to environmental change in the Alpine lacustrine regions: the displacement model, Oxford J. Archaeol., 22, 375-396, 2003.

Menotti, F.: Living on the lake in prehistoric Europe -150 years of lake-dwelling research: London, Routledge, p. 286, 2004.
Menotti, F.: Climate variations in the Circum-Alpine region and their influence on Neolithic-Bronze lacustrine communities: displacement and/or cultural adaptation, Documenta Praehistorica, 36, 61-66, 2009.

Much, M.: Erster Bericht über die Auffindung eines Pfahlbaues im Mondsee, Mitteilungen der Anthropologischen Gesellschaft in Wien, 2, 203-206, 1872.

Much, M.: Zweiter Bericht über Pfahlbauforschungen in den Oberösterreichischen Seen, Mitteilungen der Anthropologischen Gesellschaft in Wien, 4, 293-308, 1874.

Much, M.: Dritter Bericht über die Pfahlbauforschungen im Mondsee (1875-1876), Mitteilungen der Anthropologischen Gesellschaft in Wien, 6, 161-194, 1876.

Mudelsee, M., Börngen, M., Tetzlaff, G., and Grunewald, U.: No upward trends in the occurrence of extreme floods in central Europe, Nature, 425, 166-169, 2003.

Nicolussi, K., Kaufmann, M., Patzelt, G., Plicht van der, J., and Thurner, A.: Holocene tree-line variability in the Kauner Valley, Central Eastern Alps, indicated by dendrochronological analysis of living trees and subfossil logs, Veg. Hist. Archaeobot., 14, 221-234, 2005.

Offenberger, J.: Pfahlbauten, Feuchtbodensiedlungen und Packwerke. Bodenmerkmale in einer modernen Umwelt, Archaeologia Austriaca, 70, 205-236, 1986.

Offenberger, J.: Weltkulturerbe "See" - Ein Forschungsbericht, Mondseer Dokumentationen, Mondseer Museen, Mondsee, 96 pp., 2012.

Parajka, J., Kohnová, S., Bálint, G., Barbuc, M., Borga, M., Claps, P., Cheval, S., Dumitrescu, A., Gaume, E., Hlavčová, K., Merz, R., Pfaundler, M., Stancalie, G., Szolgay, J., and Blöschl, G.: Seasonal characteristics of flood regimes across the AlpineCarpathian range, J. Hydrol., 394, 78-89, 2010.

Patzelt, G.: Der zeitliche Ablauf und das Ausmass postglazialer Klimaschwankungen in den Alpen, Erdwissenschaftliche Forschung, 13, 248-259, 1977.

Pétrequin, P., Magny, M., and Bailly, M.: Habitat lacustre, densité de population et climat - L'exemple du Jura français, in: WES'04 - Wetland Economies and Societies - Collectio Archæologica 3, edited by: Della Casa, P., and Trachsel, M., Chronos, Zurich, 143-168, 2005.

Ramsey, C. B.: Radiocarbon calibration and analysis of stratigraphy: the OxCal program, Radiocarbon, 37, 425-430, 1995.

Ramsey, C. B.: Development of the radiocarbon calibration program, Radiocarbon, 43, 355-363, 2001.

Ramsey, C. B.: Deposition models for chronological records, Quaternary Sci. Rev., 27, 42-60, 2008.

Ramsey, C. B.: Bayesian analysis of radiocarbon dates, Radiocarbon, 51, 337-360, 2009.

Reimer, P. J., Baillie, M. G. L., Bard, E., Bayliss, A., Beck, J. W., Blackwell, P. G., Ramsey, C. B., Buck, C. E., Burr, G. S., Edwards, R. L., Friedrich, M., Grootes, P. M., Guilderson, T. P., Hajdas, I., Heaton, T. J., Hogg, A. G., Hughen, K. A., Kaiser, K. F., Kromer, B., McCormac, F. G., Manning, S. W., Reimer, R. W., Richards, D. A., Southon, J. R., Talamo, S., Turney, C. S. M., van der Plicht, J., and Weyhenmeyer, C. E.: IntCal09 and Marine09 radiocarbon age calibration curves, $0-50,000$ years cal BP, Radiocarbon, 51, 1111-1150, 2009.

Ruttkay, E.: Forschungsgeschichte Neolithikum in Oberösterreich und Mondseekultur im Detail - Prähistorische 
Seeufeersiedlungen im Salzkammergut, in: Visibility StudyThemenpark Mondsee, 60-71, 2003.

Ruttkay, E., Cichocki, O., Pernicka, E., and Pucher, E.: Prehistoric lacustrine villages on the Austrian lakes, in: Living on the lake in prehistoric Europe - 150 years of lake-dwelling research, edited by: Menotti, F., Routledge, London, 50-68, 2004.

Schlichtherle, H.: Lake-dwellings in south-western Germany - History of research and contemporary perspectives, in: Living on the lake in prehistoric Europe - 150 years of lake-dwelling research, edited by: Menotti, F., Routledge, London, 22-35, 2004.

Schmidt, R.: Palynologie, Stratigraphie und Großreste von Profilen der neolithischen Station See am Mondsee, Oberösterreich, Archaeologia Austriaca, 70, 227-235, 1986.

Schmidt, R.: Recent re-oligotrophication in Mondsee (Austria) as indicated by sediment diatom and chemical stratigraphy, Verhandlungen der Internationalen Vereinigung für theoretische und angewandte Limnologie, 24, 963-967, 1991.

Schmidt, R., Kamenik, C., Tessadri, R., and Koinig, K.: Climatic Changes from 12,000 to 4,000 Years Ago in the Austrian Central Alps Tracked by Sedimentological and Biological Proxies of a Lake Sediment Core, J. Paleolimnol., 35, 491-505, doi:10.1007/s10933-005-2351-2, 2006.

Schmidt, R., Kamenik, C., Kaiblinger, C., and Tessadri, R.: Klimaschwankungen und -trends des älteren Holozäns in den sülichen Niederen Tauern: multidisziplinäre Auswertung eines Sedimentkerns aus dem Oberen Landschitzsee (Lungau), in: Klimawandel in Österreich - Die letzten 20.000 Jahre... und ein Blick voraus, edited by: Schmidt, R., Matulla, C., and Psenner, R., Alpine space, 6, 55-64, 2009.

Schultze, E. and Niederreiter, R.: Paläolimnologische Untersuchungen an einem Bohrkern aus dem Profundal des Mondsees (Oberösterreich), Linzer biologische Beiträge, 22, 213-235, 1990.
Schulz, M.: Pompeji der Steinzeit, Der Spiegel, 41/2008, 160-162, 2008.

Sodemann, H. and Zubler, E.: Seasonal and inter-annual variability of the moisture sources for Alpine precipitation during 19952002, Int. J. Climatol., 30, 947-961, doi:10.1002/joc.1932, 2010.

Staubwasser, M., Sirocko, F., Grootes, P. M., and Segl, M.: Climate change at the $4.2 \mathrm{ka}$ BP termination of the Indus valley civilization and Holocene south Asian monsoon variability, Geophys. Res. Lett., 30, 1425, doi:10.1029/2002GL016822, 2003.

Swierczynski, T., Lauterbach, S., Dulski, P., and Brauer, A.: Die Sedimentablagerungen des Mondsees (Oberösterreich) als ein Archiv extremer Abflussereignisse der letzten 100 Jahre, in: Klimawandel in Österreich - Die letzten 20.000 Jahre... und ein Blick voraus, edited by: Schmidt, R., Matulla, C., and Psenner, R., Alpine space, 6, 115-126, 2009.

Swierczynski, T., Brauer, A., Lauterbach, S., Martìn-Puertas, C., Dulski, P., von Grafenstein, U., and Rohr, C.: A 1600 yr seasonally resolved record of decadal-scale flood variability from the Austrian Pre-Alps, Geology, 40, 1047-1050, doi:10.1130/g33493.1, 2012.

Swierczynski, T., Lauterbach, S., Dulski, P., Delgado, J., Merz, B., and Brauer, A.: Late Holocene flood frequency changes in the northeastern Alps recorded in varved sediments of Lake Mondsee (Upper Austria), Quaternary Sci. Rev., submitted, 2013.

Webster, J. W., Brook, G. A., Railsback, L. B., Cheng, H., Edwards, R. L., Alexander, C., and Reeder, P. P.: Stalagmite evidence from Belize indicating significant droughts at the time of Preclassic Abandonment, the Maya Hiatus, and the Classic Maya collapse, Palaeogeogr. Palaeocl., 250, 1-17, 2007.

Yancheva, G., Nowaczyk, N. R., Mingram, J., Dulski, P., Schettler, G., Negendank, J. F. W., Liu, J., Sigman, D. M., Peterson, L. C., and Haug, G. H.: Influence of the intertropical convergence zone on the East Asian monsoon, Nature, 445, 74-77, 2007. 